UDC: 378:[316.722:005.336.2]:001.895

DOI: https://doi.org/10.24195/2414-4665-2017-6-7

\author{
Tetiana Gurova, \\ PhD (Candidate of Pedagogical Sciences), associate professor, \\ Serhii Gurov, \\ PhD (Candidate of Pedagogical Sciences), associate professor, \\ Philological Department, \\ Liudmyla Moskaliova, \\ Doctor of Pedagogy, professor, head of the \\ Department of Social Work, Social and Preschool Education, \\ Melitopol State Pedagogical University named after B. Khmelnitsky, \\ 20, Hetmanska Str., Melitopol, Ukraine
}

\title{
INNOVATIVE TECHNOLOGIES IN THE FORMATION OF FUTURE ENGLISH TEACHERS' INTERCULTURAL COMMUNICATIVE COMPETENCE
}

The article deals with the innovative teaching technologies as a means of the formation of English language communication competence as an important component of future English teachers' professionalism. The experiment was aimed at assessing the effectiveness of using a set of innovative teaching technologies for the development of the above mentioned competence and involved 50 third-year students majoring in English philology who were divided into experimental and control groups. The following exercises were used in the survey as the examples of interactive teaching technologies: "Microphone", "Brainstorm", "Teaching and learning", "Associative bush", "Guess the question", "Different perception”, "Describe my favorite cultural tradition", "Idioms and proverbs", "Pros and cons corners", "Do you know the person?", What's appropriate?". According to the research results, the applied techniques contribute to the development of students' communicative competence development and also encourage them for self-development.

Keywords: competence, intercultural communicative competence, innovative technologies, future teacher of English.

\section{Introduction}

Nowadays the development of the theory and methodology of teaching future English teachers at universities is aimed at achieving definite studying results among which gaining a communicative competence is considered to be the most relevant. The growing importance of teaching future teachers the communicative competence across the world in recent years can be partly explained by shifting the focus from grammaticality and form compliance into meaning and function loyalty. Teaching communicative competence cannot be carried out without taking into consideration the cultural dialogue. Thus, it is highly important for higher pedagogical institutions to take on the vital role of the development of the modern society by designing a curriculum for future English teachers to achieve intercultural communicative competence.

Trends in the development of the modern society include the processes of integration, globalization, expansion of spheres of intercultural interaction. They covered almost all spheres of human life: economic, political, cultural and domestic. Anyway, people throughout their lives communicate with representatives of other cultures. There can be difficulties in the process of such communication, arising from a language barrier, differences in world perception and cultural peculiarities. It obviously requires the formation of tolerance and empathy, the ability for quick adaptation and modeling universal behavior patterns in order to successfully integrate and implement effective interaction. In university curricula of Ukraine there are the criteria for future employees; our country needs highly skilled professionals capable of business cooperation with foreign partners and professionals who speak a foreign language competently. Such skills and abilities are necessary for work or study abroad, for effective interaction in a multicultural team.

Without basic linguistic and cultural training of future English teachers at the university, it becomes impossible for them to teach others to become more interculturally and communicatively competent. To solve the problem we should thoroughly elaborate the training programs for English teachers aimed at the development of their intercultural competence.

The scientific literature review shows that there is an amount of theories concerning intercultural communicative competence. In publications of I. Bim, R. Milrud, P. Potter, A. Sadokhin, S. Ter-Minasova, I. Yakymanska, I. Zimnaiya $[2 ; 8 ; 11 ; 12]$, one can find the researches dealing with foreign language communication and methods for foreign language teaching. There are also lots of scientific works (for instance, by H. Gibbs, G. Gurie, D. Godson, J. Jensen, A. Crushelnytska, A. Lawson) dedicated to training highly qualified and competent specialists.

I. Zimnia believes that a student as a future specialist should have the following characteristics of a person of culture: respect of another person' dignity and preservation of one's own dignity; adequacy of behavior, culture of professional and social interaction and social life; compliance with ethnosociocultural traditions, customs, norms, etiquette in mono- and intercultural interaction. Especially important is specialist's willingness to use the 
general cultural basis of knowledge, continue personal cultural development, understand the main value-semantic dominants of the modern society [12]. Consequently, the issue of developing intercultural communicative competence of future English teacher is of particular interest nowadays.

The paper aims to define the influence of using modern innovative technologies in teaching English for the formation of intercultural communicative competence of future English teachers.

\section{Discussion}

Current requirements for teacher's professional competence are mainly accented on technological aspects of his/her activities. The role of learning English is increasing through computerization of the educational space, through the integration processes taking place in the Ukrainian education, through constructive cooperation between universities, international exchange programs and opportunities of getting education abroad.

Traditionally, language teaching in our country was focused on grammar and vocabulary reinforced by reading and writing activities. Reading and writing were primarily to help teach grammar and vocabulary rather than improve students' reading and writing skills. Teaching techniques in the $20^{\text {th }}$ century were mainly based on all around drilling and repetition, looking more like rote language learning rather than meaningful language acquisition. Almost all the syllabi of those times were grounded on grammar. Nowadays the emphasis has eventually changed as there appeared a purpose-based view of course content which shows another way of looking at constructing the working materials considering the communicative purposes that a student need a language for.

Today, the process of learning foreign languages in higher educational institutions is based on the Common European Framework of Reference for Languages, which states that while teaching any foreign language one should take into account common to all European countries purposes, content and methods of teaching. The document gives a clear description of the approach adopted in teaching for achieving a communicative competence [8]. All the requirements highlighted in CEFR lead to gradual changes in teaching process of foreign languages at universities of Ukraine. Such modernization of the teaching work is also connected with innovative processes in developing communicative competence. In the center of modern education at universities there is a student and his/her potential, that is why the main aim for a teacher is to choose methods and forms of organizing studying English carefully to meet the target of learning English at university - to acquire the communicative competence.

Thus, the Common European Framework focuses on what learners can do with a language, for instance, if a learner is able to attend a business meeting or a conference in a foreign language, use it to take notes in any subject at the university or give clear instructions for somebody to do something. A deep analysis of such "can do" requirements to a language learner offers the oppor- tunity to choose new methods and forms of presenting the modernized content and develop intercultural competence within it. This content would include systems and skills work and would clearly be organized around real world uses.

Before analyzing the innovative technologies in forming intercultural communicative competence, it is necessary to define its meaning. According to modern scientific researches, competence is considered as an independent realizable ability, based on the acquired knowledge, intellectual and life experience, values, which an individual has developed as a result of cognitive activity and educational practice. The formation of communicative competence implies the mastery of foreign-speaking communication in the unity of its functions: informative, regulative, emotionally-evaluative and ethical [6].

According to our scientific interpretation of communicative competence, it is a human ability acquired in the process of natural communication or specially organized learning. As to the structure of the communicative competence, it has the following components: linguistic (lexis, grammar, phonetics, orthography); discourse (formation of oral and written texts); pragmatic (successful achievement of a communicative goal); strategic (the overcoming of communication difficulties); sociocultural (conformity to sociocultural norms). The formation of communicative competence manifests itself in various spheres of communication, so its degree is determined by the level of mastery of skills and abilities in the main types of speaking (listening, speaking, reading, writing).

The modernization of the system of language education is based on an intercultural approach, whose main purpose in teaching a foreign language is to form intercultural communicative competence. In our research, we need to clarify the definition of intercultural communicative competence in relation to future English teachers' work. As to this point of view the term "intercultural communicative competence" can be explained as functional skills of understanding views and opinions of the representatives of other cultures, correlating one's own behavior, overcoming conflicts in the process of communication, admitting the right for existence of various values and behavioral norms. It should be noted that intercultural communicative competence creates the basis for professional mobility, preparing for rapidly changing living conditions, standards of world achievements, increases the opportunities for professional self-realization on the grounds of communication and tolerance.

When forming the intercultural communicative competence of future English teachers it is useful to keep in mind the map of language systems and language skills as an overview of the subject matter. We believe that language systems involve vocabulary, grammar, phonology, phonetics, function and discourse. As well as working on the language systems as what we keep in the head about a language itself, we also have to pay attention to what we do with the language, i.e. the ever trained skills reading, listening, writing and speaking which should be devel- 
oped in integrity. Unfortunately, some teachers underestimate the importance of skills work and try to teach new words and grammar each lesson; however, lessons should be aimed at improving students' speaking skills.

Thus, it is important to remember that there is no area of skills' or language systems' use existing in isolation: one cannot organize fruitful communication if he/she does not have command of appropriate vocabulary, and there is no reason to learn new words unless you are trained to use them in speech. The purpose of learning a language is usually to enable a person to take part in meaningful interchange of information. Sometimes traditional teaching methods were focused on learning language systems as a target and failed to provide learners with their own experience in using the linguistic knowledge.

Change of the emphasis has led to the search of new forms and methods. As a result, in recent years, the issue of the use of innovative technologies at universities has been increasingly raised. This is not only new technical means, but also new forms and methods of teaching, a new approach to the learning process. As technologies have begun to change the way English is learned in the classroom, even bigger changes seem to be taking place outside it. In fact, the digital revolution in learning now threatens to undermine the classroom completely as a place of study.

Moreover nowadays learning English by means of mobile devices gains credibility every day and the increasing popularity and rapidly diminishing cost of tablet devices reinforce this by providing a format that really is capable of delivering courseware. Thus, teachers' roles lie in keeping the balance between using innovative digital technologies and other human dependent innovative technologies, creating the proper conditions for students' practical language acquisition, in allowing students to show their learning autonomy and independent search, in activating their cognitive abilities.

Let us consider the nature of the concept of "innovation" and "innovative technology" in relation to feasibility of the use and effectiveness in teaching English. National Doctrine of Education states that Ukraine should have a boosting and outstripping development of innovative education by updating educational content and organization of the educational process in accordance with democratic values, market economy principles and modern science and technology [7].

The term "innovation in education" was implemented into the educational system of Ukraine in the period of Reformation of the Soviet educational system. Many domestic and foreign researches have been dedicated to the issues of innovative activities in the field of education: K. Anhelovsky, A. Arlamov, I. Bech, L. Vashchenko, G. Gerasimov, I. Dychkivska, V. Zhuravlev, A. Kozlov, M. Maylz, A. Nichols, A. Piechota, A. Popov, V. Slastyonin and others [1;4].

Researchers give many interpretations of the term "innovation" as G. Syrotenko describes it as a new teaching product - the result of the process of creating some- thing new, that updates the pedagogical theory and practice optimizing the achievement of public educational goals. According to R. Yusufbekov, "pedagogical innovation" is the content of possible changes in educational activities that lead to previously unknown and develop the theory and practice of teaching, i.e. the process of creation, development, use and distribution of the new [10].

Having analyzed the interpretation of this concept, we consider that innovation can mean both a result and a process. If we consider innovation as a process, it means partial or large-scale changes of the system and the corresponding human activities and innovation, and as a result - it is something new, recently established $[10,15]$. Thus, innovative educational processes emerge due to the need for social change in the educational environment, the basis and content of which lie in innovative activity of the teacher.

Innovative teaching is aimed at changing and improving the educational process in order to achieve the best results, acquire new knowledge and create new pedagogical practices. Innovative teaching is considered as the process of understanding the practical experience of teaching English, analysis of advanced experience of English teachers, the implementation of the innovative model in classroom practice focused on the formation of qualitatively new educational activities and on the development of intercultural communicative competence.

There is no doubt that the innovative teaching is teachers' creative work performed empirically, basing on a pedagogical experiment, which involves studying the effectiveness of new forms and methods of teaching [5, p. 17]. It becomes obviously useful to study the best educational experience, especially an innovative one for those who train future English teachers. The purpose of their innovative teaching lies in the creation of their own best educational experience that consists of explaining its relevance, the definition of the object and the leading idea, summarizing the theoretical framework, working out the technology of the development of experience and demonstrating the results.

Such modern teaching techniques as studying in cooperation, project methods, the use of new information technologies, the Internet resources help to implement a student-centered approach in teaching, provide individualization and differentiation of education, taking into account students' abilities, their level of training. Therefore, we believe that in order to form intercultural communicative competence of future English teachers one needs to use such technologies as ICT, project technologies, studying in cooperation, differentiation, problem solving technologies, etc.

As for ICT technologies in English classrooms, teachers can conduct their lessons using various computer resources. Almost every modern course book has extra digital materials for developing both language systems and skills. There exist a great number of computer programs which help to learn new lexical material, master the pronunciation, check up grammar and review knowledge 
on the learnt topic. The opportunities of Internet resources are enormous; the global web has created all necessary conditions for acquiring any kind of information. One can easily get any regional or cultural material within several minutes, teachers can provide classes not only with videos about different countries but also organize virtual excursions using such resources as Google map, travelgoonline.com, educatorstechnology.com, virtualfreesites.com, etc.

At the lessons, a teacher can solve different didactic tasks using the Internet and multimedia technologies: develop reading and listening comprehension skills, enhance the vocabulary, foster respect and empathy to diverse cultural traditions in English-speaking countries, motivate the inner desire to learn something new in English and activate autonomous language learning. The Internet technologies widen students' outlook; initiate the cultural dialogue with peers from English-speaking countries.

Using Internet resources and multimedia support students can take part in testing their own knowledge and skills online, participate in various videoconferences and Olympiads, have pen pals from other countries, chat on Skype, etc. The possibilities for developing intercultural competence are endless with ICT. The content basis of massive computerization is connected with understanding computer as the means of optimization of brainwork. The teacher's role here is only to create meaningful search for future English teachers and provide counseling if necessary.

It is noteworthy that the priority in acquiring intercultural communicative competence lies in developing learners' communicative and interactive abilities, authenticity in communication, achieving proficiency in English through cultural context and individual development. Nowadays the mentioned principles make it possible for intercultural competence to grow up. The final goal in learning English is to teach learners to feel confident in foreign environment and form their ability to react adequately in various cultural situations.

In this regard, it is useful to say that one of the fundamental assumptions today about teaching English is that it occurs when students learn more by doing things themselves rather than by being told what to do. Taking it into consideration it is necessary to provide classes with cooperation and interaction technologies of teaching English. This suggests, for example, that it may be more useful not only to learn a dialogue or listen a teacher's story about how correctly to order a meal but also to role-play it in a café with the following feedback or suggestions. Thus, interactive technologies within the communicative approach contribute to the development of students' intercultural communicative competence.

The communicative approach enriched by technologies of cooperation and interaction becomes an efficient strategy which models communication aimed at the creation of psychological and linguistic readiness to speak a foreign language, conscious comprehension of the materi- al and ways of dealing with it. A communicative task should propose a problem for students to solve or a topic to discuss, what is more students not only share the information but also assess it with the help of criteria worked out beforehand. The main advantage of using a communicative approach in developing intercultural competence of future English teachers is providing students with an opportunity to choose linguistic units independently.

The technology of cooperation or the so-called interactive technology also belongs to modern innovative technologies. Its basic idea lies in creating the conditions for successful collaboration of students in different educational situations. According to G. Selevko, it has the following characteristics: according to the level of application - general pedagogical; according to philosophical basis - humanistic; according to focusing on personality structure - every kind of harmonious; according to the content - educational, humanistic, comprehensive, penetrating, by its type of control: a system of small groups; as to organizational forms - academic and club or individual; as to the approach to the child - humane and personal [9].

There is a division of interactive learning technologies into four groups: studying in pairs, frontal teaching, learning while playing, learning while discussing [4, p. 22]. Group learning activities are characterized by a change in the number of participants from two to five people in a group. The group challenges a common goal, the development of communication skills and intercultural competence as well. There are also interactive teaching technologies which involve work of the whole group of students, namely discussion ("Microphone", "Brainstorm", "Teaching and learning", "Associative bush", etc.). As for the teaching techniques based on playing (such as role-play and dramatization), they simulate different life situations and are the most favorite ones for future English teachers, because here they have some freedom of intellectual activity, presenting assumptions and solving problem situations. The teacher in this case plays the role of a facilitator and a consultant. A technology "Learning while discussing" is an important way to motivate and encourage cognitive activities in the process of discussion. Students learn to defend their points of view, to formulate their principles and respect others. The result of the debate may be either coming to a consensus or remaining unconvinced [3, p. 48].

Here we give an example of some activities we used at university while conducting the experiment.

Warm up activity "Guess the question".

A teacher starts the session by writing different words on the board: (the USA, red, film, railway station, restaurant, president, Lincoln, milk, garden, friends...). The students are suggested to ask as many questions as they can for the proposed words to be the answers. This activity is aimed at teaching students to predict possible questions; it generates their interest at the beginning of 
the lesson and develops their ability to ask questions spontaneously.

1. Activity "Different perception".

The students are given the same sheets of paper. The teacher gives the commands what to do with this paper. The instruction: (Close your eyes, fold your paper in half, tear the upright corner, fold in half again, tear the left down corner of your paper, fold in half and tear the upper left corner and fold it again to tear the right down corner, then unfold it). Everybody follows the instruction carefully, at the end students can see different patterns of their sheets of paper. The aim of the activity to show different ways of perceiving the same information.

2. Activity "Describe my favorite cultural tradition".

Students are asked to draw their favorite cultural tradition in the family. After it, they exchange their works and cooperate to describe each other's pictures. This activity helps to raise awareness of different cultural traditions and also develops communicative competence.

3. Activity "Idioms and proverbs"

The students are divided into two groups. They are given a number of idioms and expressions. Their task is to find their equivalents in their native language.

4. Activity "Pros and cons corners"

Students are suggested the topic "Working in a foreign country". There are posters with written words "pros" and "cons" on the classroom walls. Students are suggested different statements, their task is to choose their position and substantiate it.

5. Activity "Do you know the person?"

All the participants are divided into groups. The groups members are given the photos of people from different cultural groups. Students have about 15 minutes to give the characteristics to the person on the photo (name, origin, age, profession, background...). This activity helps to develop communicative competence; it also shows the stereotypical perception in describing people of different cultural groups. After completing this activity, it is reasonable to ask the following questions: Did you have any difficulties in describing people? What influenced your descriptions? Can the conclusions about one's personality be made by only having seen the appearance?

6. Activity "What's appropriate?"

Students are divided into two groups. They are given cards with different traditions in various countries. The sentences describing traditions are incomplete. Their task is to guess the final part of the tradition. The group who gives more correct answers - wins.

The results of studying scientific sources on the mentioned issue serve as the basis for an experimental verification of the pedagogical principles of forming intercultural communicative competence of future English teachers. As a result of the study we developed a model of forming up intercultural communicative competence of future English teachers. The research and experimental work was organized in accordance with the basic requirements for conducting a pedagogical experiment (Y. Babansky, S. Goncharenko, N. Kuzmina) and it was held at Melitopol State Pedagogical University named after Bogdan Khmelnytskyi.

Pedagogical experiment was conducted within the framework of the disciplines "Major foreign language" and "Country studies". The experiment involved 50 students of the third year of study who were divided into control (CG ) and experimental groups (EG). Quantitative and qualitative indicators derived from the results of the preliminary stage of the experiment led to the conclusion that the levels of intercultural competence are homogeneous.

In this regard, it should be noted that basing on the results of the use of the psychological and pedagogical principles of forming intercultural communicative competence of future English teachers, we have outlined the following criteria 1) professional-lingual competence and its intercultural aspect; 2) logical competence and its intercultural aspect; 3) intercultural socio-psychological competence. During the pedagogical experiment, there was an intermediate and final testing.

In order to assess the level of the development of intercultural communicative competence according to vocational speech competence and its intercultural aspect, we used written test tasks corresponding to the distinguished levels of intercultural communicative competence. Thus, students were offered tasks for recognition, choice and use of units of speech etiquette and speech acts for the restoration of speech elements of the text, as well as assignments with freely-constructed answers without reliance on speech patterns.

In order to assess the level of the development of search and analytical skills that make up the logical competence, a set of written test tasks was used. The students of the experimental group were offered tasks for the search, perception, comprehension, extraction and analysis of factual and intercultural aspects of information. At the same time, the analysis implies the definition of a universal cultural value, reflected by an appropriate element of information. The students of the control group were offered tasks for perception, comprehension and extraction of factual aspects of information. The fulfillment of tasks on perception and comprehension of information involves understanding the content, the identification of its cultural orientation or socio-cultural aspects, as well as logics of exposition. For diagnosing the level of the third criterion the students were proposed to write a letter of request using a stereotyped sample of a business letter.

The result of processing and analysis of the received data is given in Table 1 . 
Table 1.

The dynamics of the levels of manifestation of intercultural communicative competence

\begin{tabular}{|c|c|c|c|c|c|}
\hline \multirow[b]{2}{*}{ Criteria } & \multirow[b]{2}{*}{ levels, \% } & \multicolumn{2}{|c|}{ Before the experiment } & \multicolumn{2}{|c|}{ After the experiment } \\
\hline & & $\begin{array}{c}\text { EG } \\
23 \text { people }\end{array}$ & $\begin{array}{c}\text { CG } \\
27 \text { people }\end{array}$ & $\begin{array}{c}\text { EG } \\
23 \text { people }\end{array}$ & $\begin{array}{c}\text { CG } \\
27 \text { people }\end{array}$ \\
\hline \multirow{3}{*}{$\begin{array}{l}\text { vocational speech } \\
\text { competence and its } \\
\text { intercultural aspect }\end{array}$} & high & 11 & 10.2 & 55.2 & 28.1 \\
\hline & average & 27.2 & 25.7 & 23.7 & 48.9 \\
\hline & low & 61.8 & 64.1 & 21.1 & 23 \\
\hline \multirow{3}{*}{$\begin{array}{c}\text { logical competence } \\
\text { and its intercultural } \\
\text { aspect }\end{array}$} & high & 14 & 12.5 & 48.9 & 15 \\
\hline & average & 32.2 & 29.1 & 34 & 36.8 \\
\hline & low & 53.8 & 58.4 & 17.1 & 48.2 \\
\hline \multirow{3}{*}{$\begin{array}{l}\text { intercultural socio- } \\
\text { psychological compe- } \\
\text { tence }\end{array}$} & high & 12.2 & 10.7 & 51.1 & 13.8 \\
\hline & average & 26,8 & 24.9 & 42.3 & 46.9 \\
\hline & low & 61 & 64.4 & 6.6 & 39.3 \\
\hline
\end{tabular}

The comparison of the results showed that in the group where we used innovative interactive technology to form intercultural communicative competence the average score has increased significantly. According to the first criterion, there has been observed a change in the number of students with the high level from $11 \%$ to $55.2 \%$, according to the second criterion - a significant growth from $14 \%$ to $48.9 \%$, and according to the third criterion $12.2 \%$ to $51.1 \%$.

Apart from this, we took into consideration an expert evaluation of other teachers who proved the increase of the level of students' communicative competence within the experiment time in comparison with the control group. Thus, the students of the experimental group could fluently communicate, they could ask and answer questions on

\section{REFERENCES}

1. Angelovskiy, K. (1991). Uchitelya $i$ innovatsii [Teachers and innovations]. Moscow [in Russian].

2. Byram, Michael (2004). Assessing Intercultural Competence in Language Teaching. Sprogforum, 18, pp. 8-13 (Vol. 6). Retrieved from: dpb.dpu.dk/infodok/sprogforum/Espr18/byram.html [in English].

3. Common European Framework of Reference for Languages: Learning, Teaching, Assessment (2001). Cambridge University Press [in English].

4. Fedorchuk, E. (2006). Suchasni pedahohichni tehnolohii [Modern pedagogic technologies]. KamyanetsPodilsk [in Ukrainian].

5. Pometun, O., Pirozhenko, L. (2002). Interaktivnye tehnologii obucheniya: teoriya, opyt [Interactive teaching tehnologies: theory, experience]. Kyiv: Academy of pedagogical science [in Ukrainian].

6. Knapp, K., Knapp-Potthoff, A. (1990). Interkulturelle Kommunikation [Intellectual communication]. Zeitschrift fur Fremdsprachenforschung - Journal of foreign languages researching, 1, 83 [in German].

7. Natsionalna doktryna rozvytku osvity. Sertyfikovanyi za ukazom Prezydenta Ukrainy v 2002 rotsi [National Doctrine of Education Development. Certified by different topics, comment the points of view and cooperate with each other.

\section{Conclusion}

A thorough analysis of scientific resources and practical experience of teaching English in pedagogical university have proved that the current model of education is difficult to imagine without using innovative technologies. The results of the conducted research give us reason to assert that application of activities within innovative technologies has a positive impact on the formation and development of intercultural communicative competence of students. The further research studies are planned to assess the effectiveness of the implementation of other teaching techniques into foreign language training taking into account the level of students' abilities.

the decree of the President of Ukraine in 2002]. Retrieved from: http://www.president.gov.ua/documents/151.html. [in Ukrainian].

8. Sadokhin, A. P. (2008). Mezhkulturnaya kompetentnost i kompetentnost v sovremennoy kommunikatsii [Intercultural competence and competence in modern communication]. Sotsyalnyie nauki $i$ sovremennost - Social sciences and modernity, 3, 156166 [in Russian].

9. Selevko, G. K. (1998). Sovremennye obuchayushie tehnologii [Modern studying technologies]. Moscow, Narodnoye obrazovaniye [in Russian].

10. Sirotenko, G. O. (2005). Innovatsiinii rozvytok osviti: Problemy perekhodu vid praktyky do teorii [Innovative development of education: Problems of transition from practice to theory]. Upravlinnya shkoly - School management, 1, 15-18 [in Ukrainian].

11. Volkova, N. P. (2007). Pedagogika [Pedagogy]. Kiev: Academic public house [in Ukrainian].

12. Zimnyaya, I. A. (2003). Klyuchevye kompetentsii - novaya paradigma rezultata obrazovaniya [Key competences as a new paradigm of the result of education]. Moscow: Publishing House: Visshee obrazovanie segodnya [in Russian]. 


\section{ЛІТЕРАТУРА}

1. Ангеловский К. Учитель и инновации / К. Ангеловский. - Москва, 1991. - 134 с.

2. Байрам Майкл. Оценка межкультурной компетенции в преподавании языка [Електронний ресурс] / Майкл Байрам // Sprogforum, № 18, Vol. 6, pp. 8-13. Retrieved March 4, 2004. - Режим доступу до ресурсу: dpb.dpu.dk/infodok/sprogforum/Espr18/byram.html

3. Common European Framework of Reference for Languages: Learning, Teaching, Assessment.

Cambridge University Press, 2001, - P. 24.

4. Федорчук Е. Сучасні педагогічні технології / Е. Федорчук / Підручник. - Кам'янець-Подільськ, 2006. -213 c.

5. Пометун О. Інтерактивні технології вивчення: теорія, досвід / О. Пометун, Л. Пироженко. - Київ: Академія педагогічних наук. 2002. - 136 с.

6. Knapp K., Interkulturelle Kommunikation / K. Knapp, A. Knapp-Potthoff // Zeitschrift fur Fremdsprachenforschung. - 1990. - № 1. - P. 83.
7. Національна доктрина розвитку освіти. Сертифікований за указом Президента України в 2002 році [Е-ресурс] // - Режим доступу до ресурсу: http://www.president.gov.ua/documents/151.html.

8. Садохин А.П. Межкультурная компетентность и компетентность в современной коммуникации. (Опыт системного анализа) / А.П. Садохин // Социальные науки и современность. - 2008. - № 3. - С. 156-166.

9. Селевко Г. К. Современные обучающие технологии: Учебник. / Г. К. Селевко. - Москва, Народное образование, $1998 .-256 \mathrm{c.}$

10. Сиротенко Г. О. Інноваційний розвиток освіти: проблеми переходу від практики до теории / Г. О. Сиротинко // Управління школами, - 2005. - С. 15-18.

11. Волкова Н. П. Педагогіка / Н. П. Волкова. Київ: Академічне видавництво, 2007. - 616 с.

12. Зимняя И.А. Ключевые компетенции - новая парадигма результата образования / И.А. Зимняя // Высшее образование сегодня, 2003. - No5. - С. 34-42.

Тетяна Юріӥвна Гурова, кандидат педагогічних наук, доиент, Сергій Юрійович Гуров, кандидат педагогічних наук, дочент, кафедра англійської філологї̈ та методики викладання англійської мови,

Людмила Юріївна Москальова,

доктор педагогічних наук, професор, завідувач кафедри соціальної роботи, сочіальної педагогіки та дошкільної освіти, Мелітопольський державний педагогічний університет імені Богдана Хмельницького, вул. Гетьманська, 20, м. Мелітополь, Украӥна

\section{ВИКОРИСТАННЯ ІННОВАЦЙНИХ ТЕХНОЛОГІЙ У ФОРМУВАННІ МІЖКУЛЬТУРНОЇ КОМУНІКАТИВНОӤ КОМПЕТЕНТНОСТІ МАЙБУТНІХ УЧИТЕЛІВ АНГЛІЙСЬКОӤ МОВИ}

Підвищення якості викладання англійської мови в університеті пов'язане з упровадженням інноваційних технологій в навчальний процес. У статті зосереджено увагу на змінах у пріоритетах під час вивчення іноземної мови, розглянуто визначення поняття «міжкультурна комунікативна компетентність» з позиції підготовки професійного спеціаліста. Мета дослідження - визначити вплив сучасних інноваційних технологій у викладанні англійської мови на формування міжкультурної комунікативної компетентності майбутніх учителів англійської мови. Ретельний аналіз наукових ресурсів і практичний досвід викладання англійської мови в педагогічному університеті довели, що нинішню модель освіти важко уявити без використання інноваційних технологій. Розвиток теорії і методики викладання англійської мови майбутнім вчителям сьогодні спрямований на досягнення навчальних результатів, серед яких комунікативна компетентність вважається найбільш важливою. Зростання ії ролі частково пояснюється зміщенням акценту у викладанні англійської у бік функціональності і значущості мови, але слід відзначити, що розвиток комунікативної компетентності сьогодні неможливий без урахування діалогу культур, саме тому вважаємо важливим спрямовувати педагогічні зусилля на формування міжкультурної комунікативної компетентності майбутніх вчителів англійської мови, що може бути здійснено за допомогою таких інноваційних технологій, як-от: інформаційно-комунікативні технології в мовних класах, проектні технології, технології співпраці (інтерактивні технології), організації різних видів портфоліо тощо. У статті аналізуються особливості використання зазначених технологій на практичних заняттях з англійської мови, а також наведено приклад роботи зі студентами експериментальної групи, де було впроваджено комплекс вправ для формування міжкультурної комунікативної компетентності на основі інтерактивних технологій. Серед вправ, які було використано під час експерименту, відзначимо такі: «Вгадай запитання», «Різне сприйняття», «Опиши свою найулюбленішу традицію», «діоми та прислів’я», «Протилежні кути», «Чи знаєте Ви людину?», «Що є доречним?». За допомогою методу аналізу результатів діяльності було виявлено зростання рівня сформованості міжкультурної комунікативної компетентності студентів наприкінці експерименту. Це підтверджує те, що використання інноваційних технологій на заняттях з англійської мови має позитивний вплив на формування міжкультурної комунікативної компетентності.

Ключові слова: компетентність, міжкультурна комунікативна компетентність, інноваційні технології, майбутні учителі англійської мови.

Submitted on May, 17, 2017 